\title{
A palynological investigation of some Lower Kimmeridgian deposits from Spain
}

\author{
A. W. van ERVE \\ Veba Oel AG, Abteilung 51 P.O. Box 2010 45, Gelsenkirchen 4650, BRD, Fed. Rep. of \\ Germany. \\ R. E. BESEMS \\ EPX/36, Shell Internationale Petroleum Mij. B.V., Postbus 162, 2501 AN, The Hague, \\ The Netherlands. \\ C. F. LOVE \\ XGL/1, Syria Shell Petroleum Development B.V., P.O. Box 3633, Damascus, Syria.
}

\begin{abstract}
The present paper provides the first palynological data from two ammonite controlled sections from the Lower Kimmeridgian (Sutneria platynota Ammonite Zone) in Spain. The Segura de la Sierra sequence is located in the Betic Cordilleras and the Hontanar sequence is located in the Iberian Chain. The palynological assemblages, dominated by dinoflagellate cysts and sporomorphs, include taxa which are well known from other areas to be long-ranging throughout the major part of the Mesozoic. Most noteworthy is the presence of Cicatricosisporites spp. in the material investigated. The impact of this on the assumption that a strong diachronous south-north migration of this taxon existed during Middle and Late Jurassic times is discussed.
\end{abstract}

\section{INTRODUCTION}

Age assessments of Jurassic sedimentary rocks from the Iberian Peninsula have generally been based on faunal evidence, especially ammonites, although occasionally, due to the absence of palaeontological control, assessments have also been established on lithostratigraphical criteria. So far few Jurassic palynological records are available from this area. Most of these concern Portugal (Riley, 1974; Adloff et al., 1977; Adloff \& Doubinger, 1978; Williams \& Bujak, 1985; Davies, 1985; Van Erve \& Mohr, in press) and little is known about the Jurassic microfloral development in Spain.

To increase the palynological information on the Jurassic of the Iberian Peninsula two Lower Kimmeridgian ammonite controlled sections from different structural units in Spain have been investigated: (1) the Segura de la Sierra section of the Betic Cordilleras and (2) the Hontanar section of the Iberian Chain (Fig. 1). In both sequences some samples were taken from ammonite bearing strata which have been assigned to the Sutneria platynota Ammonite Zone. This zone represents the earliest Kimmeridgian of the Tethyan realm and is generally assumed to be time-equivalent to the Pictonia baylei Ammonite Zone of the Boreal realm (Fig. 2).

\section{THE SEGURA DE LA SIERRA SECTION}

Location. The Segura de la Sierra section is located north-east of the village of Segura de la Sierra (province of Jaén) along the road to Siles (Lopez Garrido, 1971; Fig. 1).

Geological setting. In the province of Jaén, the Prebetic Zone is one of the structural units of the Betic Cordilleras, the Alpine fold-belt of southern Spain (Hermes, 1978; Alvarado, 1980). Lopez Garrido (1971) recognized three distinct structural sub-units in this area which approximately correspond to palaeogeographical domaines: (1) Unit of Beas de Segura, (2) Unit of Sierra de Cazorla and (3) Unit of Sierra del Segura.

In the former two units only Jurassic deposits are present, whereas in the latter Cretaceous sediments are also encountered. The Segura de la Sierra section is part of the Unit of Sierra del Segura and represents predominantly shallow marine Jurassic-?Cretaceous deposits, uncomfortably overlain by the continental Cretaceous sediments of the so-called "Utrillas" (Lopez Garrido, 1971).

Stratigraphy (Figure 3). No formal lithostratigraphical subdivision has been established in the Unit of Sierra del Segura. However, Lopez Garrido (1971) distinguished several lithological intervals, which, on the basis of their stratigraphical position or fossil content, have been recognized throughout the province of Jaén. The Jurassic-?Cretaceous intervals exposed in the Segura de la Sierra section can be briefly summarized in ascending order (Lopez Garrido, 1971): 
Interval 1: $80-100 \mathrm{~m}$ of massive grey non-fossiliferous dolomites. It is considered to represent the Lias and ?Dogger.

Interval 2: $8-10 \mathrm{~m}$ of grey-yellow nodular limestones containing a rich ammonite fauna. The basal part contains numerous Divisosphinctes spp. and Euaspidoceras sp., Ochetoceras marantianus (D'Orbigny), Taramelliceras flexuousus pinguis (Quenstedt), Taramelliceras flexuosus auritus (Quenstedt), Taramelliceras sarasani Loriol, Taramelliceras pictus costatus (Quenstedt). In the upper part Perisphinctes
(Orthosphinctes) tiziani (Oppel), Lithacoceras (Progeronia) pseudopolyplocoides Geyer and Glochiceras (Lingulaticeras) lingulatus (Quenstedt) are also present. The lower part of this interval is considered to represent the Late Oxfordian (Epipeltoceras bimammatum Ammonite Zone), whereas the upper part represents the transition to the basal Kimmeridgian.

Interval 3: $50-60 \mathrm{~m}$ of alternating limestones, marly limestones and marls. Three sub-units have been recognized:-the lowermost $15 \mathrm{~m}$ comprise marly limestones with marl intercalations. Abundant ammonites
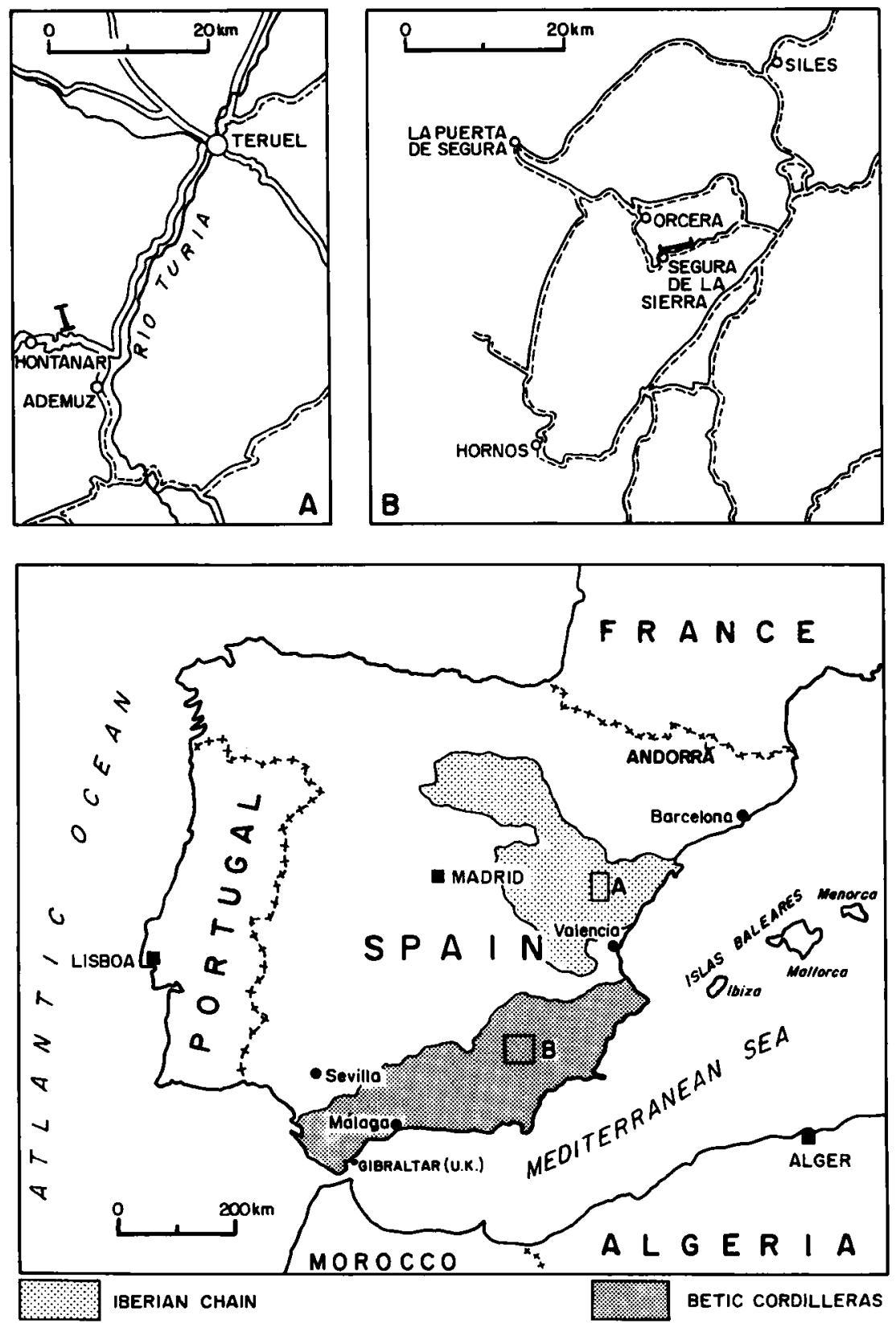

Fig. 1. Location Map. A: Hontanar section. B: Segura de la Sierra section. 


\begin{tabular}{|c|c|c|}
\hline \multirow[b]{2}{*}{ STAGES } & \multicolumn{2}{|c|}{ AMMON I TE ZONES } \\
\hline & $\begin{array}{l}\text { N.W.EUROPE } \\
\text { (BOREAL) }\end{array}$ & $\begin{array}{l}\text { S.EUROPE } \\
\text { (TETHYAN) }\end{array}$ \\
\hline $\begin{array}{c}\text { EARLY } \\
\text { KIMMERIDGIAN } \\
\text { SENSU ANGLICO }\end{array}$ & $\begin{array}{l}\text { AULACOSTEPHANUS AUTISSIODORENSIS } \\
\text { AULACOSTEPHANUS EUDOXUS } \\
\text { AULACOSTEPHANUS MUTABILIS } \\
\text { RASENIA CYMODOCE } \\
\text { PICTONIA BAYLEI }\end{array}$ & $\begin{array}{l}\text { HYBONOTICERAS BECKERI } \\
\text { AULACOSTEPHANUS EUDOXUS } \\
\text { ASPIDOCERAS ACANTHICUM } \\
\text { CRUSSOLICERAS DIVISUM } \\
\text { ATAXIOCERAS HYPSELOCYCLUM } \\
\text { SUTNERIA PLAYNOTA }\end{array}$ \\
\hline OXFORDIAN & $\begin{array}{l}\text { RINGSTEADIA PSEUDOCORDATA } \\
\text { DECIPIA DECIPIENS } \\
\text { PERISPHINCTES CAUTISNIGRAE } \\
\text { GREGORYCERAS TRANSVERSARIUM } \\
\text { PERISPHINCTES PLICATILIS } \\
\text { CARDIOCERAS CORDATUM } \\
\text { QUENSTEDTOCERAS MARIAE }\end{array}$ & $\begin{array}{l}\text { IDOCERAS PLANULA } \\
\text { EPIPELTOCERAS BIMAMMATUM } \\
\text { PERISPHINCTES BIFURCATUS } \\
\text { GREGORYCERAS TRANSVERSARIUM } \\
\text { PERISPHINCTES PLICATILIS } \\
\text { CARDIOCERAS CORDATUM } \\
\text { QUENSTEDTOCERAS MARIAE }\end{array}$ \\
\hline
\end{tabular}

Fig. 2. Oxfordian and Early Kimmeridgian Ammonite Zonations (after Hallam, 1975).

have been recorded: e.g. Sutneria platynota (Reinecke), Sowerbyceras silensus (Fontannes), $\mathrm{Ha}$ ploceras tenuifalcatus (Neumayr), Ataxioceras sp., Ataxioceras polyplocus breviceps (Quenstedt), Ataxioceras (Parataxioceras) cf. schneidi Geyer, Ataxioceras (Parataxioceras) sp., Lithacoceras sp. and Phylloceras sp. This part is assigned to the Early Kimmeridgian (Sutneria platynota Ammonite Zone, Fig. 2). - the middle $27 \mathrm{~m}$ are formed of marly limestones with marl intercalations. Ostracods, radiolarians, echinoderms and globochaetes have been recorded. - the uppermost $13-15 \mathrm{~m}$ comprise an alternation of marls, limestones and marly limestones. Ostracods, radiolarians, foraminifera and sponge spicules have been recorded.

Interval 4: $35 \mathrm{~m}$ of well-bedded grey dolomites. Although no fossils have been recorded, a Kimmeridgian age has been assigned to this unit on lithostratigraphical considerations.

Interval 5: $1-3 \mathrm{~m}$ of whitish coloured limestones. A few fragments of gastropods and charophytes have been observed.

Lithostratigraphical correlations with adjacent areas suggest this unit represents the Portlandian?Neocomian.

This sequence is uncomformably overlain by Cretaceous green marls and white sands of the "Utrillas" of Interval 6 and the yellowish sandy dolomites of Interval 7.

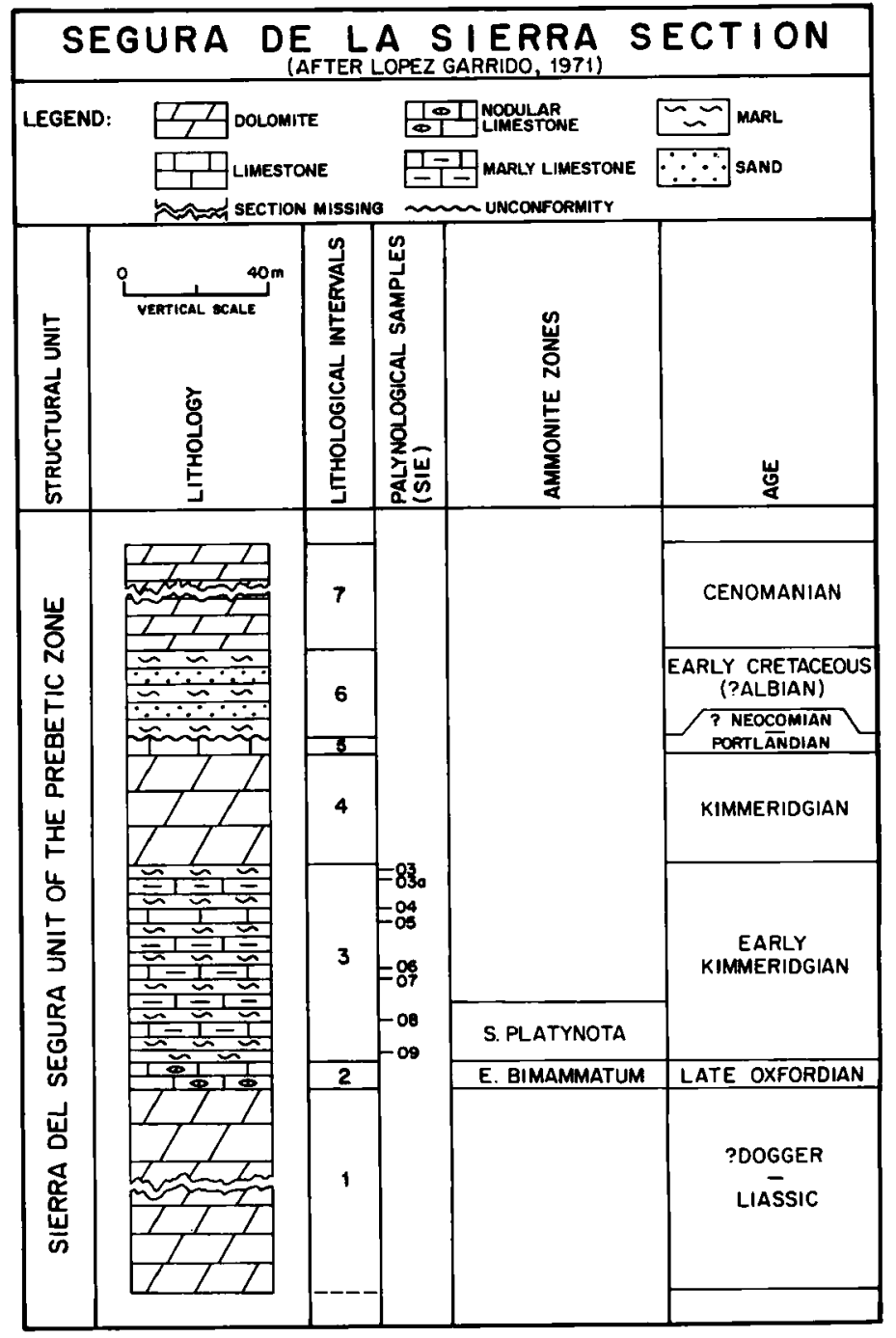

Fig. 3. Stratigraphy and sample position of the Segura de la Sierra section. 


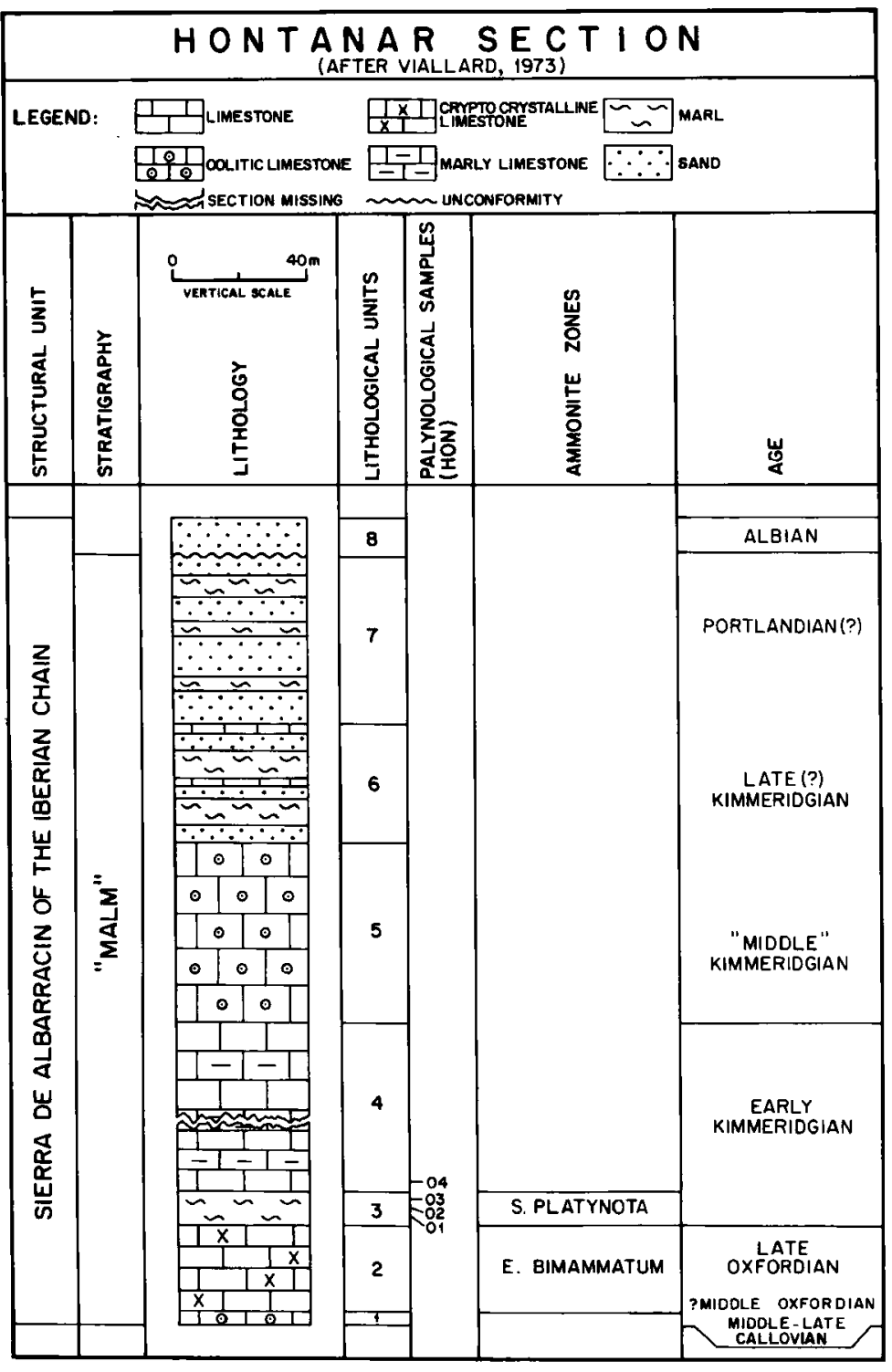

Fig. 4. Stratigraphy and sample position of the Hontanar section.

\section{THE HONTANAR SECTION}

Location. The Hontanar section is located along the road Teruel-Cuenca (province of Teruel) between kilometer poles 185-186 (Viallard, 1973; Fig. 1).

Geological setting. The section is part of the Sierra de Albaracin, one of the structural units of the Iberian Chain (Viallard, 1973). In this unit the Precambrian and Palaezoic Hercynian basement is covered by thick more or less complete sequences of Mesozoic and Palaeogene sediments. As a result of tectonics, major differences are apparent in the palaeogeographical configuration of the Jurassic and Cretaceous sedimentary basins.

Stratigraphy (Figure 4). No formal lithostratigraphical subdivision of the Jurassic has been established in this area and the lithostratigraphy, as in the Segura de la
Sierra, is discussed in terms of Liassic, Dogger and Malm. In the Hontanar section the Malm is exposed. The Callovian to Middle Oxfordian sequence is very condensed and the Lower Oxfordian seems to be missing. Within the Hontanar section 7 lithological units have been distinguished. These units will be briefly discussed in a ascending order (Viallard, 1973): Unit 1: approximately $0.30 \mathrm{~m}$ of oolithic limestone. Viallard (1973) assigned a Middle-Late Callovian to possibly Middle Oxfordian age for this unit.

Unit 2: $25 \mathrm{~m}$ of cryptocrystalline limestones. The fossil record contains ammonites, e.g. Ochetoceras mariantianum (D'Orbigny), Orthosphinctes polygyratus (Quenstedt) and Orthosphinctes tiziani (Oppel), protoglobigerinas and sponges. Based on the ammonites, 
the upper part of this unit has been assigned to the Late Oxfordian Epipeltoceras bimammatum Ammonite zone (Fig. 2).

Unit 3: $10 \mathrm{~m}$ of grey marls. Ammonites have been recorded from this unit, e.g. Idoceras sp. and Sutneria platynota (Reinecke). Based on the latter taxon this unit has been assigned to the Early Kimmeridgian Sutneria platynota Ammonite zone (Fig. 2).

Unit 4: $100 \mathrm{~m}$ thick sequence of cryptocrystalline limestones with intercalations of marly limestones. Ammonites have been recorded from this unit: Perisphinctes (Lithacoceras) aff. riberoi Choffat, Lithacoceras cf. subachilles Wegele and Lithacoceras cf. virgatoides Wegele. Based on the fossil content, Viallard (1973) assigned an Early Kimmeridgian age.

Unit 5: $50 \mathrm{~m}$ of thick bedded sub-lithographical or oolitic, microcrystalline limestones. The fossil record contains a variety of echinoderms (Cidarids).

Unit 6: $35 \mathrm{~m}$ of fine sands and silty marls with intercalations of microcrystalline limestone beds. On the basis of the foraminifera taxa Alveosepta jaccardi (Schrodt) a Kimmeridgian age has been assigned.

Unit 7: $70 \mathrm{~m}$ of fine micaceous sands and silty marls. Based on lithostratigraphical considerations a Late Kimmeridgian to Portlandian age has been assigned.

The Malm sequence is uncomfortably overlain by Cretaceous (Albian) deposits which constitute argillaceous sands with quartz pebbles of the "Utrillas".

\section{PALYNOLOGY}

Sampling. Twelve samples from the two sections described were taken and prepared, using standard palynological techniques. Eight samples are from Interval 3 of the Segura de la Sierra section (Figure 3); three samples from unit 3 and one sample from unit 4 of the Hontanar section (Figure 4). From the Hontanar section only samples HON 01 and HON 03 provided palynological assemblages, whereas samples HON 02 and HON 04 proved to be barren.

The samples were collected during a field excursion of the Laboratory of Palaeobotany and Palynology of the Utrecht State University, The Netherlands, in the early spring of 1979 .

Annotated species list. The following taxa have been recognised in the palynological assemblages investigated. The taxonomical classification of the palynomorphs was mainly based on publications by Couper (1958), Burger (1966), Vigran \& Thusu (1975), Dörhöfer (1979), Herngreen et al. (1980), Hunt (1985) and Thusu \& Vigran (1985). For genera identification the Genera File of Jansonius \& Hills (1976) was consulted. Therefore, no other papers are included in the reference list. Full references to the dinoflagellate cysts cited can be found in Lentin \& Williams, 1985. Those taxa marked by an asterisk are further discussed in the systematics section.

\section{Spores}

Aequitriradites sp.

Antulsporites clavus (Balme, 1957) Filatoff, 1975.

Araucariacites australis Cookson, 1947.

Baculatisporites comaumensis (Cookson, 1953) Potonié, 1956.

Biretisporites potoniaei (Delcourt \& Sprumont, 1955) Delcourt, Dettmann \& Hughes, 1963.

Calamospora mesozoica Couper, 1958.

Cibotiumspora juriensis (Balme, 1957) Filatoff, 1975 (Plate I, Fig. 1).

Cicatricosisporites spp. (Plate I, Figs. 4-6).

Concavisporites spp. (Plate I, Fig. 3).

Concavissimisporites spp.

Contignisporites cooksonii (Balme, 1957) Dettmann, 1963.

Convolutispora spp.

Deltoidospora mesozoica (Thiergart, 1949) Schuurman, 1977.

Deltoidospora minor (Couper, 1958) Pocock, 1970.

Densoisporites velatus Weyland \& Krieger, 1953.

Echinatisporis spp.

Foraminisporis spp.

Gleicheniidites senonicus Ross, 1949 (Plate I, Fig. 2).

Ischyosporites variegatus (Couper, 1958) Schulz, 1967

(Plate I, Fig. 9).

Kraeuselisporites sp.

Leptolepidites proxigranulatus (Brenner, 1963) Dörhöfer, 1979.

Leptolepidites spp.

Lycopodiacidites intraverrucatus Benner, 1963.

Marattisporites scabratus Couper, 1958.

Osmundacidites wellmanii Couper, 1953.

Reticulatisporites spp.

Retitriletes spp.

Rubinella major (Couper, 1958) Norris, 1969 (Plate I, Fig. 7).

Spheripollenites spp. (Plate I, Figs. 11, 12).

Staplinisporites caminus (Balme, 1957) Pocock, 1962.

Taurocusporites segmentatus Stover, 1962.

Todisporites major Couper, 1958.

Todisporites minor Couper, 1958.

Trilobosporites spp.

Tuberositriletes spp.

Uvaesporites argenteaeformis (Bolchovitina, 1953) Schulz, 1967 (Plate I, Fig. 8).

Varirugosisporites spp.

\section{Pollen}

Bisaccate pollen undifferentiated.

Callialasporites dampieri (Balme, 1957) Sukh Dev, 1961 (Plate I, Fig. 10).

Callialasporites microvelatus Schulz, 1966.

Callialasporites minus (Tralau, 1968) Guy, 1971.

Callialasporites trilobatus (Balme, 1957) Sukh Dev, 1961 (Plate I, Fig. 15).

Callialasporites turbatus (Balme, 1957) Schulz, 1967 
(Plate I, Fig. 16).

Callialasporites segmentatus (Balme, 1957) Srivastava, 1963.

Cerebropollenites macroverrucosus (Thiergart, 1949) Schulz, 1967.

Corollina spp. (Plate I, Fig. 14).

Cycadopites spp.

Ephedripites spp.

Exesipollenites tumulus Balme, 1957 (Plate I, Fig. 13).

Perinopollenites elatoides Couper, 1958.

\section{Dinoflagellate cysts}

Apteodinium cf. nuciforme (Deflandre, 1938b) Stover \& Evitt, 1978 (Plate 2, Fig. 5).

Apteodinium nuciforme (Deflandre, 1938b) Stover \& Evitt, 1978.

Chlamydophorella? cf. membranoidea* Vozzhennikova, 1967 (Plate 2, Figs. 7, 10).

Chytroeisphaeridia chytroeides (Sarjeant, 1962a) Downie \& Sarjeant, 1963 emend. Davey, 1979 (Plate 2, Fig. 8).

Cleistosphaeridium spp.

Cribroperidinium granuligerum (Klement, 1960) Stover \& Evitt, 1978 (Plate 2, Fig. 9).

Cribroperidinium spp.

Ctenidodinium cf. panneum (Norris, 1965) Lentin \& Williams, 1973.

Dichadogonyaulax sellwoodii Group* sensu Woollam, 1983 (Plate 2, Fig. 2).

Dingodinium tuberosum (Gitmez, 1970) Fisher \& Riley, 1980 (Plate 2, Fig. 11).

Dinoflagellates indeterminable.

Egmontodinium? ovatum (Gitmez \& Sarjeant, 1972) Riley, 1979.
Ellipsoidictium spp.

Epiplosphaera spp.

Escharisphaeridia pocockii (Sarjeant, 1968) Erkman \& Sarjeant, 1980.

"Gonyaulacysta complex"* sensu Jan du Chêne, Masure et al., 1986 (Plate 2, Figs. 1, 4).

Gonyaulacysta jurassica (Deflandre, 1938) Norris \& Sarjeant, 1965.

Hystrichosphaerina orbifera (Klement, 1960) Stover \& Evitt, 1978.

Leptodinium spp.

Mendicodinium groenlandicum (Pocock \& Sarjeant, 1972). Davey, 1979.

Meristaulax cf. granulata (Klement, 1960) Sarjeant, 1984.

Meristaulax granulata (Klement, 1960) Sarjeant, 1984.

Pareodinia ceratophora Deflandre, 1947.

Pareodinia spp.

Scrinodinium crystallinum (Deflandre, 1938) Klement, 1960.

Scrinodinium spp.

Sentusidinium cf. rioultii (Sarjeant, 1968) Sarjeant \& Stover, 1978 (Plate 2, Fig. 6).

Sentusidinium pilosum (Ehrenberg, 1854) Sarjeant \& Stover, 1978.

Sirmiodinium grossii Alberti, 1961.

Systematophora areolata Klement, 1960 (Plate 2, Fig. $3)$.

Tubotuberella apatela (Cookson \& Eisenack, 1960) loannides et al., 1977 emend. Sarjeant, 1982.

Tubotuberella lurida (Deflandre, 1938) Davies, 1983. Valensiella ovula (Deflandre, 1947) Eisenack, 1963. Wallodinium cf. glaessneri* (Cookson \& Eisenack, 1960) Loeblich \& Loeblich, 1968.

\section{Explanation of Plate 1}

All Figures approx. $\times 1000$ magnification.

Fig. 1. Cibotiumspora juriensis (Balme, 1957) Filatoff, 1975 sample SIE-08.

Fig. 2. Gleicheniidites senonicus Ross, 1949 sample SIE-08.

Fig. 3. Concavisporites spp. sample SIE-09.

Figs. 4,5,6. Cicatricosisporites spp. Fig. 4: sample SIE-08. Fig. 5: sample SIE-06. Fig. 6: sample SIE-09.

Fig. 7. Rubinella major (Couper, 1958) Norris, 1969 sample SIE-05.

Fig. 8. Uvaesporites argenteaeformis (Bolchovitina, 1953) Schulz, 1967 sample SIE-09.

Fig. 9. Ischyosporites variegatus (Couper, 1958) Schulz, 1967 sample SIE-05.

Fig. 10. Callialasporites dampieri (Balme, 1957) Sukh Dev, 1961 sample SIE-09.

Figs. 11,12. Spheripollenites spp. sample SIE-09.

Fig. 13. Exesipollenites tumulus Balme, 1957 sample SIE-09.

Fig. 14. Corollina spp. (tetrad) sample SIE-05.

Fig. 15. Callialasporites trilobatus (Balme, 1957) Sukh Dev, 1961 sample SIE-09.

Fig. 16. Callialasporites turbatus (Balme, 1957) Schulz, 1967 sample SIE-05. 
Lower Kimmeridgian Palynology of Spain
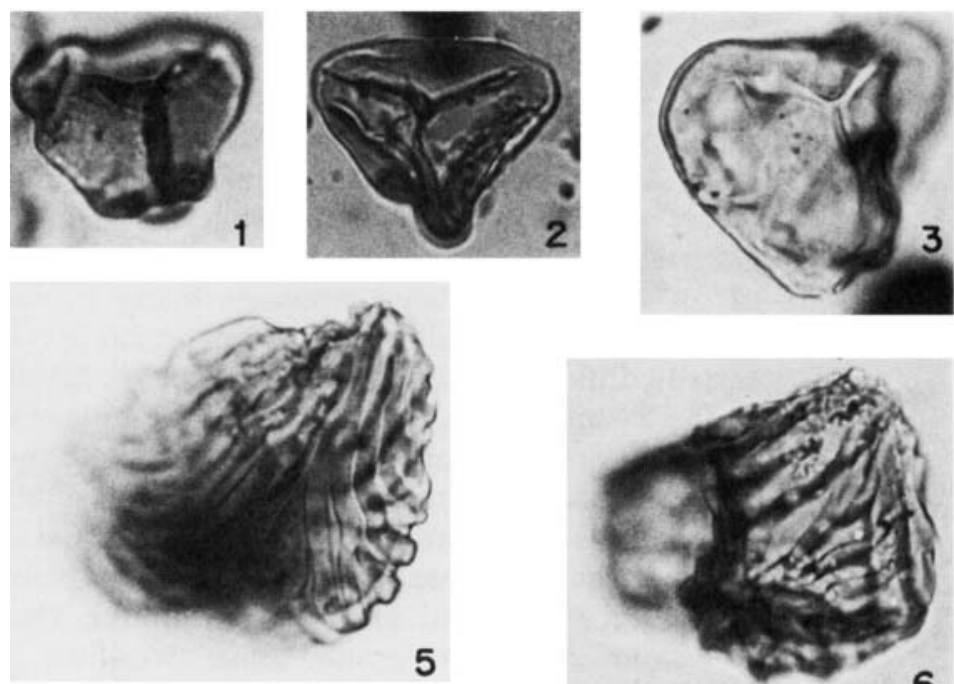

5
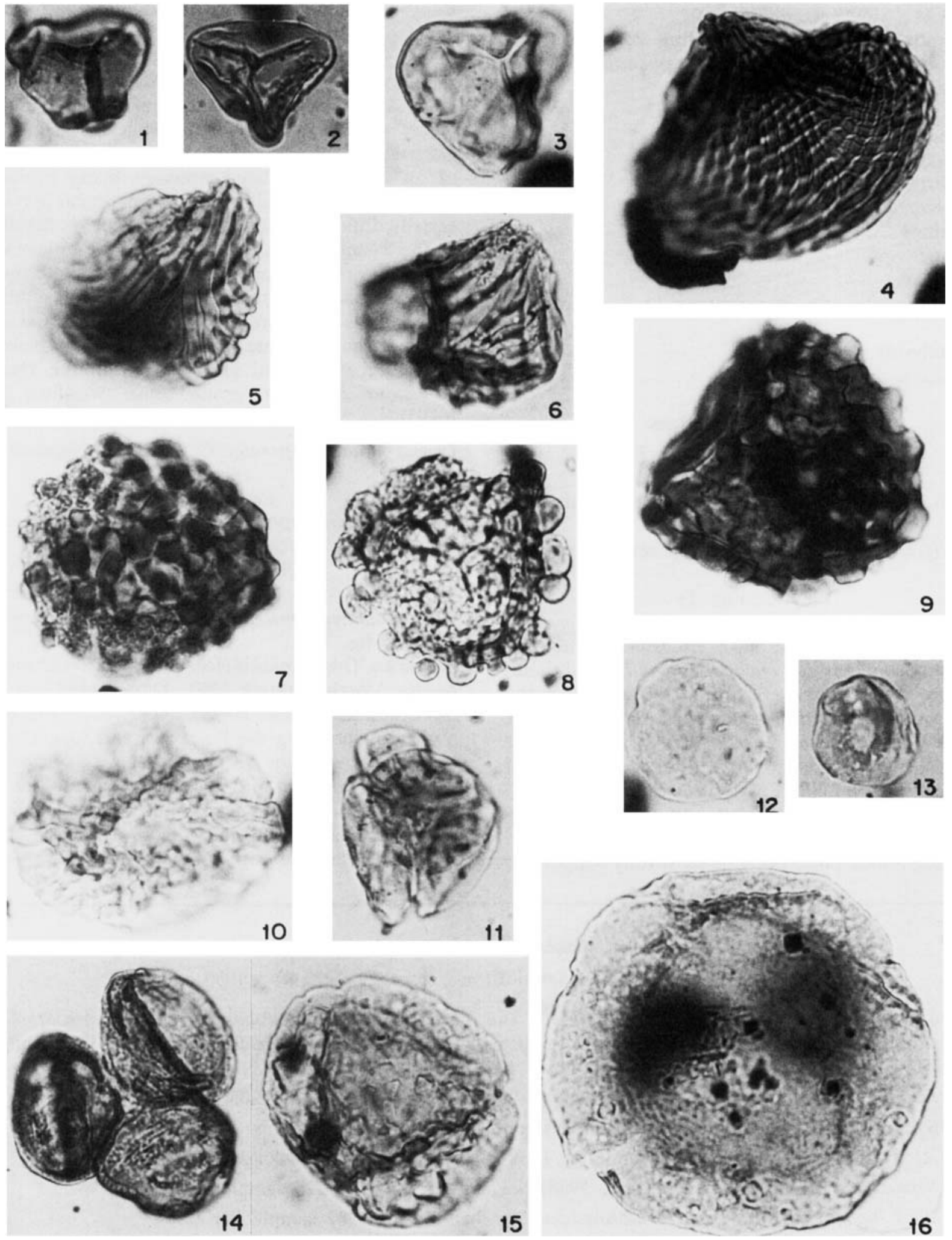
Acritarchs

Acantomorphy acritarchs (including Micrhystridium spp., Baltisphaeridium spp., Solisphaeridium spp.). Algae sensu lato

Circulisporites parvis De Jersey 1963.

Botryococcus spp.

Prasinophytes

Cymatiosphaera spp.

Pterospermella spp.

Tasmanitids

Tasmanites spp.

Scolecodonts

Schistomeringos expectatus Szaniawski \& Gazdzicki, 1978.

Foraminiferids

Trochiliascia spp.

\section{Systematic descriptions}

Class Dinophyceae Fritsch, 1929.

Order Peridiniales Haeckel, 1894.

Genus Dichadogonyaulax Sarjeant, 1966 emend. Woollam, 1983.

Dichadogonyaulax sellwoodii Group sensu Woollam, 1983.

(Plate 2, Fig. 2)

Remarks. Several authors have discussed the taxonomic relationship between Dichadogonyaulax and Ctenidodinium Woollam (1983, p.193) differentiates the genera "primarily on the asymmetry of the paracingular crests". Whilst Benson (1985, p.147-8) seperates the genera "on the basis of the postventral displacement of the pre-apical paraplate". The comment of Benson $(1985, \mathrm{p} .145)$ that the differentiation of species within the complex is often easier than deciding in which genus the species should be placed is fully supported.
Benson also suggests that the differentiation by the development of paracingular crests is variable, impossible to observe in highly compressed specimens and should not be used to seperate dinocysts at a generic level. Although agreeing that development of crests are highly variable and an undesirable characteristic for generic separation, it seems that his use of the presence of an apical paraplate, although being probably a unique morphological feature, for practical purposes is equally difficult to apply. This difficulty is highlighted in the Spanish material where the poor presentation makes the recognition of an apical paraplate impossible, whereas the crest morphology can readily be interpreted. Therefore the symmetry of the paracingular crests and the fine, long crestal spines places the morphotype recorded in Spain within the Dichadogonyaulax sellwoodii group sensu Woollam (1983, p.193).

Genus Chlamydoporella Cookson \& Eisenack 1958 emend.

Duxbury 1983.

Chlamydophorella? cf. membranoidea

Vozzhennikova 1967

(Plate 2, Figs. 7, 10)

1982 Chlamydophorella? membranoidea Davey; 27, plate 8 , fig. 12 .

Remarks. This species is closely related to $C$.? membranoidea Vozzhennikova 1967. Davey $(1982$, p.27) in discussing this species notes the occasional presence of a corona, including the holotype, and suggests this is due to intra-specific variability. Davey suggests that C.? membranoidea probably ranges from the basal Kimmeridgian to the Late Hauterivian, although notes that specimens possessing a corona have not been observed below the Early Portlandian (kerbus) Ammo-

\section{Explanation of Plate 2 \\ All Figures $\times 650$ magnification except Figs. 7, $10 \times 1000$.}

Figs. 1, 4. "Gonyaulacysta complex" sample SIE-08. The specimen figured is probably conspecific with Meristaulax angulosa (Gitmez, 1970) Sarjeant \& Gocht in Sarjeant 1984, however the species was so rare that it has been recorded under the "Gonyaulacysta complex".

Fig. 2. Dichadogonyaulax sellwoodii Group sensu Woollam, 1983 sample SIE-08.

Fig. 3. Systematophora arealata Klement, 1960 sample SIE-08.

Fig. 5. Apteodinium cf. nuciforme (Deflandre, 1938) Stover \& Evitt, 1978 sample SIE-08.

Fig. 6. Sentusidinium cf. rioultii (Sarjeant, 1968) Sarjeant \& Stover, 1978 sample SIE-08.

Figs. 7,10. Chlamydophorella? cf. membranoidea Vozzhennikova, 1967 sample SIE-08.

Fig. 8. Chytroeisphaeridia chytroeides (Sarjeant, 1962) Downie \& Sarjeant, 1963 emend. Davey, 1979 sample SIE-08. The operculum can be observed in the cyst interior.

Fig. 9. Cribroperidinium granuligerum (Klement, 1960) Stover \& Evitt, 1978 sample SIE-08.

Fig. 11. Dingodinium tuberosum (Gitmez, 1970) Fisher \& Riley, 1980 sample SIE-08. 

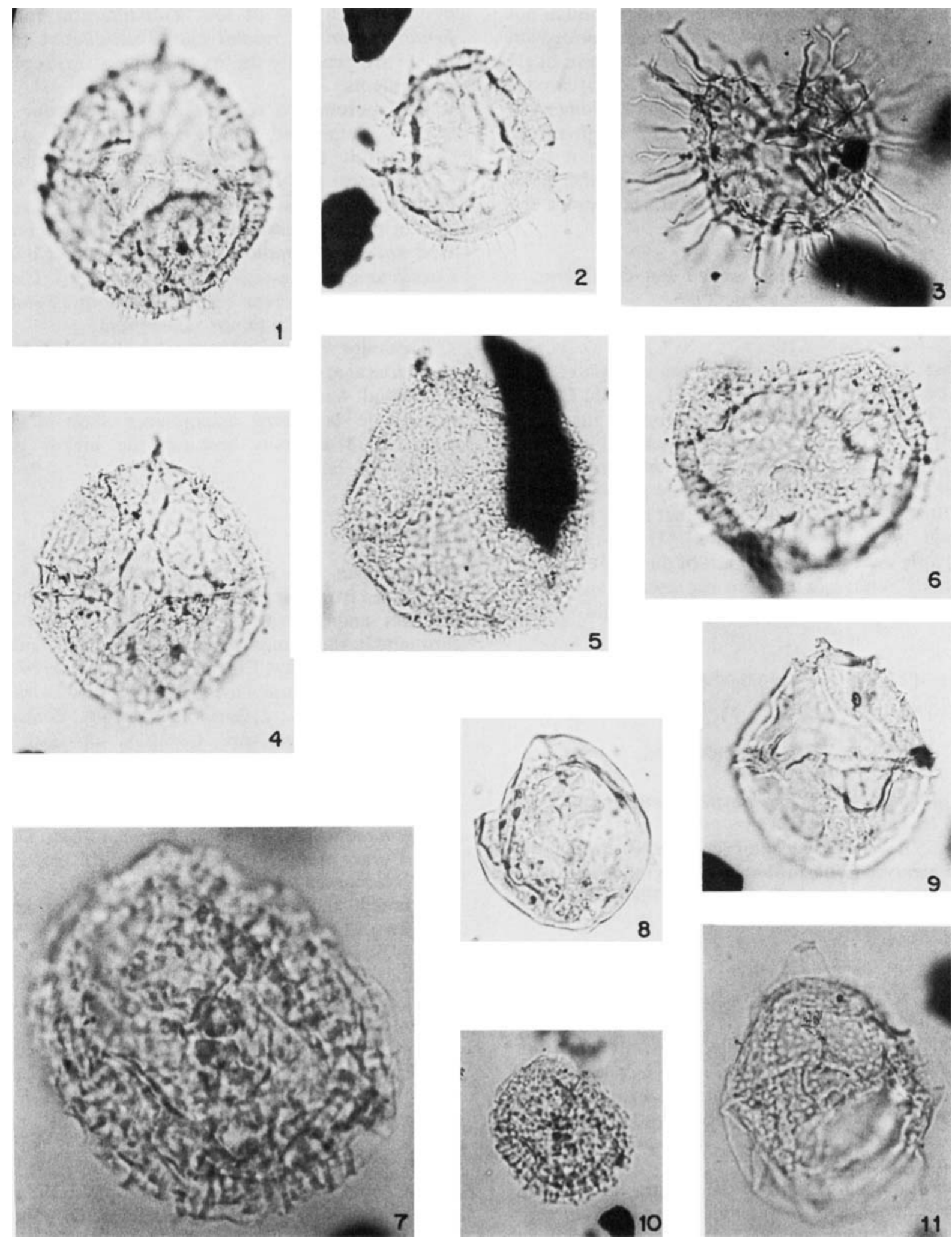
nite Zone. The species recorded in Spain although not possessing a discernable corona are synonomous with C.? membranoidea sensu Davey (1982). It seems likely however, that the presence or absence of a corona, linked to an indication of a stratigraphical element to this variability, would suggest two species are involved. Hence the forms recorded in Spain have not been assigned to $C$. membranoidea, although the poor quality of the material in Spain could not support the erection of a new species.

\section{"Gonyaulacysta complex" sensu Jan du Chêne, Masure et al. 1986. \\ (Plate II, Figs. 1, 4)}

Remarks. The term "Gonyaulacysta complex" was coined by Stover \& Evitt (1978, p.271). Jan du Chêne, Masure et al. (1986 p.15) also adopted this term although incorporating several new genera, including Apteodinium and Meristaulax (which they synonymize with Cribroperidinium). The generally poor preservation of the Spanish material means that many dinocysts could not be positively identified. However, many could clearly be recognised as part of the "Gonyaulacysta complex" and probably are representatives of the genera Apteodinium, Cribroperidinium, and Meristaulax.

Genus Wallodinium Loeblich \& Loeblich, 1968. Wallodinium cf. glaessneri (Cookson \& Eisenack 1960b)

Loeblich \& Loeblich 1968.

1980 Wallodinium cf. W. glaessneri Courtinat \& Galliard p. 68, pl. 2, fig. 11 .

Remarks. The single specimen recorded is comparable with $W$. glaessneri and probably synonymous with that described by Courtinat \& Gaillard (1980) from the Upper Oxfordian.

\section{GENERAL COMPOSITION OF THE ASSEMBLAGES}

The samples investigated yielded relatively moderate diversified but rather poorly preserved palynomorphs. The relative frequencies and distribution of the taxa recognised are presented on Figures 5 and 6. The plots were made within S.I.P.M., EPX/36 with the Checklist programme of $\mathbf{J}$. Phillips.

The sporomorph content of the Segura de la Sierra assemblages is generally dominated by Corollina spp. and Spheripollenites spp. All other sporomorph taxa are minor constituents although occasionally Concavisporites spp. can be present in higher proportions. Noteworthy is the persistent occurrence of Cicatricosisporites spp. Acantomorph acritarchs, dinoflagellate cysts forming part of the "Gonaulacysta complex", Sentusidinium cf. rioultii and Apteodinium cf. nuciforme are generally the most frequent microplankton constituents.

The sporomorph content of the Hontanar assemblages is dominated by Spheripollenites spp. All other sporomorph taxa are minor constituents although Corollina spp. and Exesipollenites tumulus may occur in higher proportions. It should be noted that due to the overall poor preservation some specimens referred to Exesipollenites tumulus may represent inner bodies of Corollina spp. (see also Riley, 1974; p.36). Cicatricosisporites spp. has been recorded in both assemblages. Microplankton is a minor constituent.

The major difference between the Segura de la Sierra and Hontanar assemblages is that the latter are less diversified and contain fewer microplankton. The Segura de la Sierra assemblages show a general decrease in diversity towards the higher part of Interval 3.

\section{DISCUSSION}

Sporomorphs. The majority of taxa which have been recognised from the sections investigated occur in both Tethyan and Boreal realms. Some of them range throughout the larger part of the Jurassic and Cretaceous of Northwest Europe, e.g. Deltoidospora spp., Gleicheniidites senonicus, Ischyosporites variegatus, Leptolepidites spp., Spheripollenites spp. Todisporites spp., Callialasporites spp., Corollina spp. and Taurucosporites segmentatus, while other taxa are known from the Upper Jurassic onwards, e.g. Cicatricosisporites spp., Concavissimisporites spp., Leptolepidites proxigranulatus and Trilobosporites spp. (e.g. Couper, 1958; Burger, 1966; Vigran \& Thusu, 1975; Dörhöfer, 1979; Herngreen et al., 1980, Hunt, 1985).

Although the bulk of taxa are present in both Tethyan and Boreal areas, the composition of Middle to Late Jurassic assemblages from these areas are quite different. This difference has already been discussed by Thusu \& Vigran (1985). Although these authors do not discuss coeval Early Kimmeridgian assemblages, the composition of the Spanish sporomorph fraction in broad terms resembles that of other Jurassic Tethyan assemblages from the Sahara and north-eastern Libya being dominated by Corollina spp. and Spheripollenites spp. with scarce bisaccate pollen grains. (see also Reyre, 1973; Riley, 1974; Thusu \& Vigran, 1985; Van Erve \& Mohr, in press.). Assemblages from the Boreal area however show a reverse combination (Thusu \& Vigran, 1985).

Most noteworthy in the sporomorph content of the samples investivated is the presence of Cicatricosisporites spp. According to Dörhöfer (1979, fig. 4), this taxon evolved and migrated from lower palaeolati- 
tudes (10 degrees) in the Callovian of North Africa towards the north. At a palaeolatitude of ca 20 degrees ( $=$ approx. Iberian peninsula) it would appear in the Oxfordian and at a palaeolatitude of ca 30 degrees (North-west Europe) its first appearance would be in the Upper Kimmeridgian. However, the palynological data available do not support this theory: (1) the presence of indigenous Cicatricosisporites spp. in the "Callovian" of North Africa is rather doubtful. The palynological data from North Africa used by Dörhöfer (1979) is based on the work of Reyre (1973). This author used subsurface cutting material and reports the first (= bottom) appearance of Cicatricosisporites spp. at the base of his zone 5B of presumed Middle Callovian to Late Jurassic age. Reyre's Zone 5B accommodates the "Callovo-OxfordianKimmeridgian" (litho-) stratigraphical unit and the age assessments of this unit has been based on both stratigraphical/palaeontological and palynological criteria. The Middle Callovian age for the base of this unit has been established by stratigraphical correlations with the Tazerdunet outcrop section. The major part of this outcrop section is dated Callovian-Oxfordian by means of ammonites, whereas its upper part probably represents the Kimmeridgian (Reyre, 1973). The Late Jurassic age of the top part of the "Callovo-OxfordianKimmeridgian" unit is adopted on palynological criteria: the presence of Cicatricosisporites spp. and Trilobosporites spp. The lowermost appearance of very few specimens of Cicatricosisporites spp. in the "Callovo-Oxfordian-Kimmeridgian", definitely not caved from the overlying units, is only reported in the well DB-1, where this (litho-) unit of $160 \mathrm{~m}$ thickness reaches surface. In the upper part of this unit Cicatricosisporites spp. has been recorded together with Trilobosporites spp. However, from Reyre's data it is not conclusive whether Cicatricosisporites spp. are present in the lower part of the "Callovo-OxfordianKimmeridgian" unit in well DB-1, and if so, that they are indigenous and have not been caved from the upper part of this unit. In conclusion it can be stated that, at present no strong evidence is available for the first appearance of Cicatricosisporites spp. in the "Middle" Callovian.

(2) the presence of Cicatricosisporites spp. in the Sutneria platynota zone of earliest Kimmeridgian age from Spain is the oldest known occurrence from the Iberian peninsula (compare Van Erve \& Mohr, in press.). (3) In Northwest Europe Cicatricosisporites spp. have been recorded from strata referred to the Rasenia cymodoce Zone (Vigran \& Thusu, 1975; Thusu \& Vigran, 1975), which represents the equivalent of the zone overlying the Sutneria platynota Zone (Fig. 2).

From this it is obvious that the assumption of a strong diachronous migration of Cicatricosisporites spp. from lower to higher palaeolatitudes on the northern hemi- sphere is speculative and not supported by palynological data.

Microplankton. Although Gitmez (1970) describes microplankton assemblages from the Pictonia baylei zone of North-west Europe, there are relatively few other publications discussing microplankton assemblages specifically from the earliest Kimmeridgian. Also in the Tethyan realm no records are available: in the Upper Bathonian-Tithonian interval described by Thusu \& Vigran (1985) no marine Lower Kimmeridgian deposits have been recorded. However, the Lower Kimmeridgian interval is considered in several Upper Jurassic zonal schemes notably Fisher \& Riley (1980) (Leptodinium egemenii subzone) and Woollam \& Riding (1983) $(\mathrm{Gj} / \mathrm{Sc}(\mathrm{c})$ subzone). In general the microplankton assemblages described from these publications are all fairly similar being dominated by species of the "Gonyaulacysta complex," normally with common G. jurassica, Hystrichogonyaulax cladophora, and species of Leptodinium. The assemblages also typically contain Sentusidinium spp. and with varying records of chorate dinocysts.

In some respects the assemblages recorded in Spain are similar to those mentioned above, particularly in the dominance of species of the "Gonyaulacysta complex". However $G$. jurassica, which is normally frequent in Northwest European Early Kimmeridgian assemblages, although present in Spain, is only recorded in low numbers and $H$. cladophora is not recorded at all.

The other apparently major difference is the presence of species of Dichadogonyaulax and Ctenidodinium with high parasutural ornament in the Spain material. Ctenidodinium chondrum Drugg 1978, which has low parasutural ornament, is the only published species of these genera from the Early Kimmeridgian. This apparent difference is probably a reflection of the lack of published data, since several forms, similar to those recorded in Spain, have been frequently noted to occur in borehole material from the Kimmeridgian of the North Sea (CFL pers. obs.).

Of palynostratigraphical interest is that both the publications on zonal schemes mentioned above note the last stratigraphical occurrence of Scriniodinium crystallinum in the Pictonia baylei zone and significantly this form is also recorded in Spain. Equally Woollam \& Riding (1983) note the first appearance of Dingodinium tuberosum in the earliest Kimmeridgian $\mathrm{Gj} / \mathrm{sc}(\mathrm{c})$ subzone, again a species recorded in Spain. 


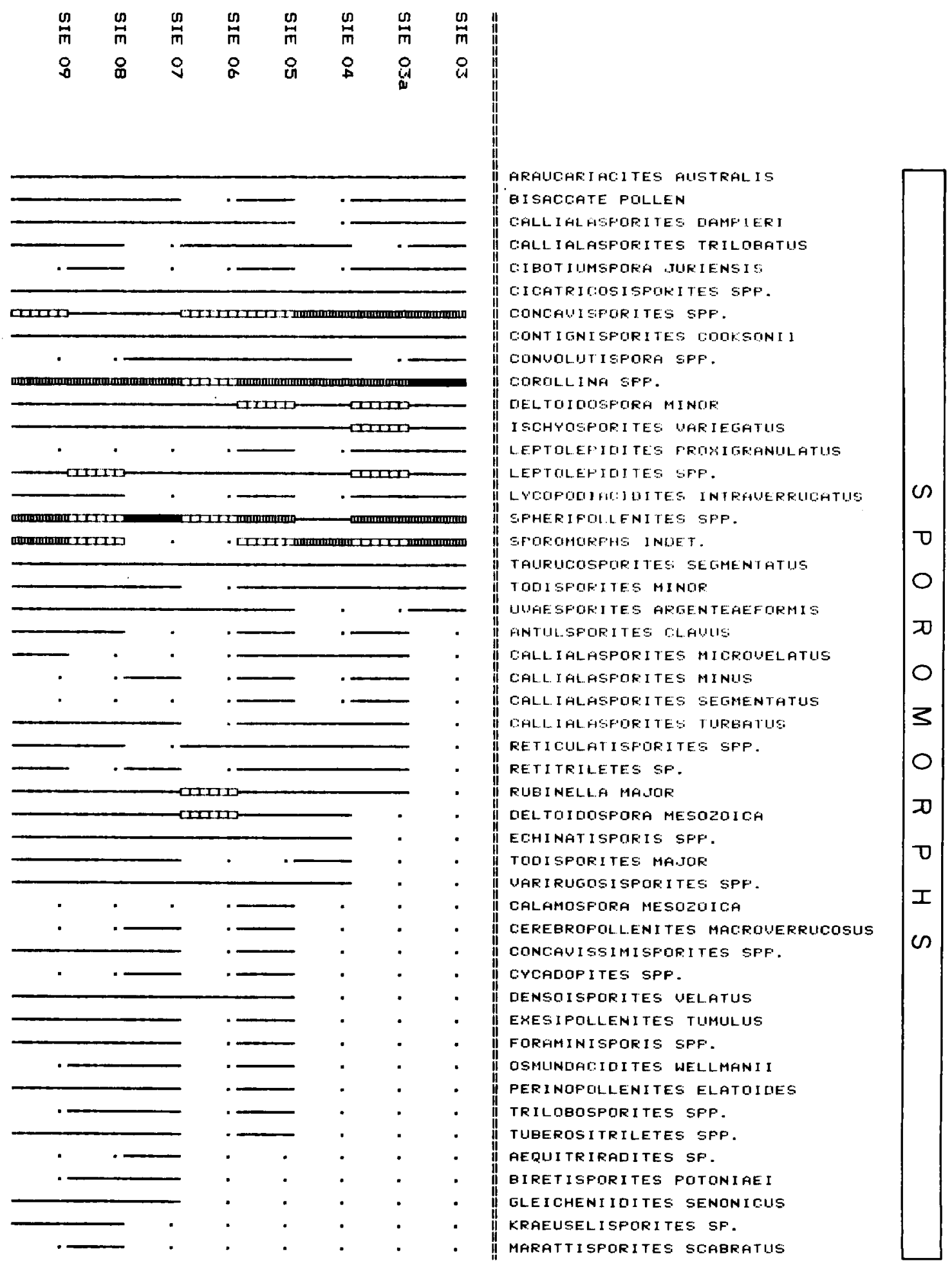

Fig. 5. Distribution chart Segura de la Sierra section. 


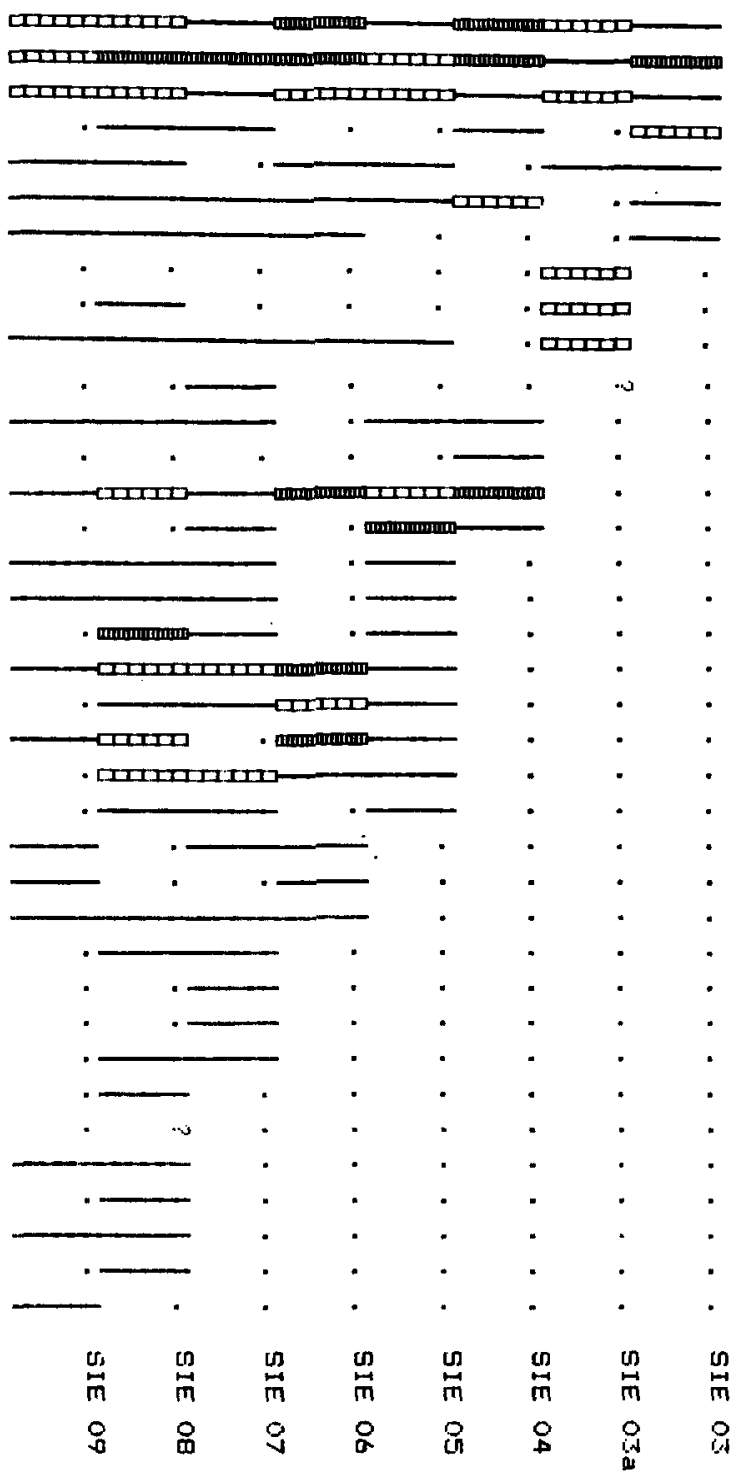

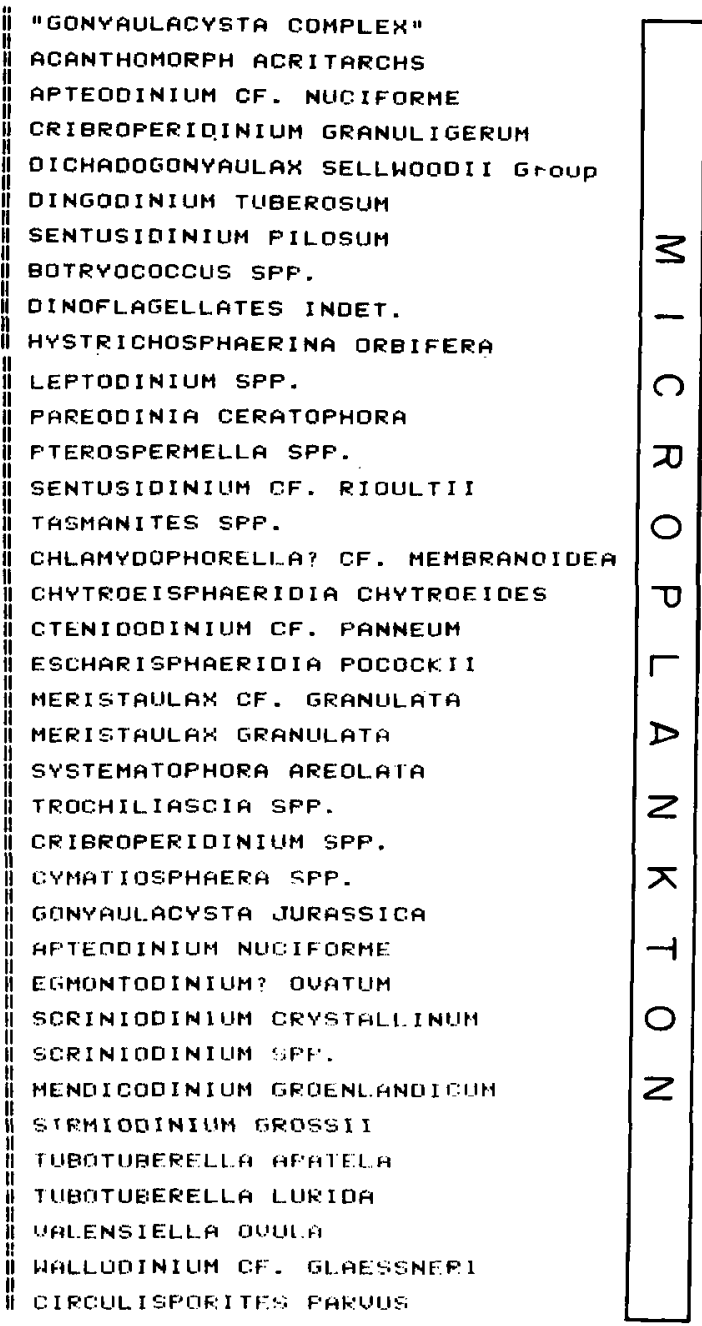

Fig. 5. Distribution chart Segura de la Sierra section. 
rey to Symbols

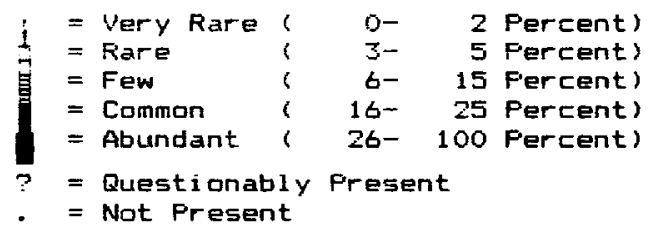

\begin{tabular}{|llllllllllll}
\hline & $S$ & $P$ & $O$ & $R$ & $O$ & $M$ & $O$ & $R$ & $P$ & $H$ & $S$ \\
\hline
\end{tabular}

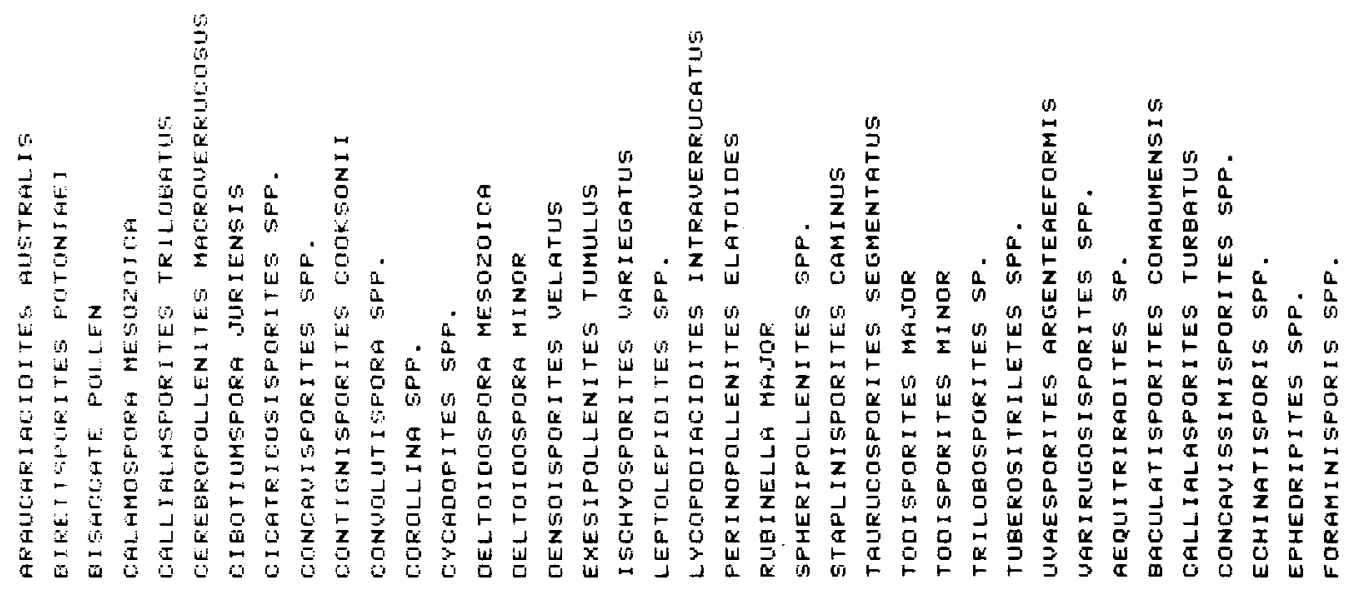

HON 03

HON 01
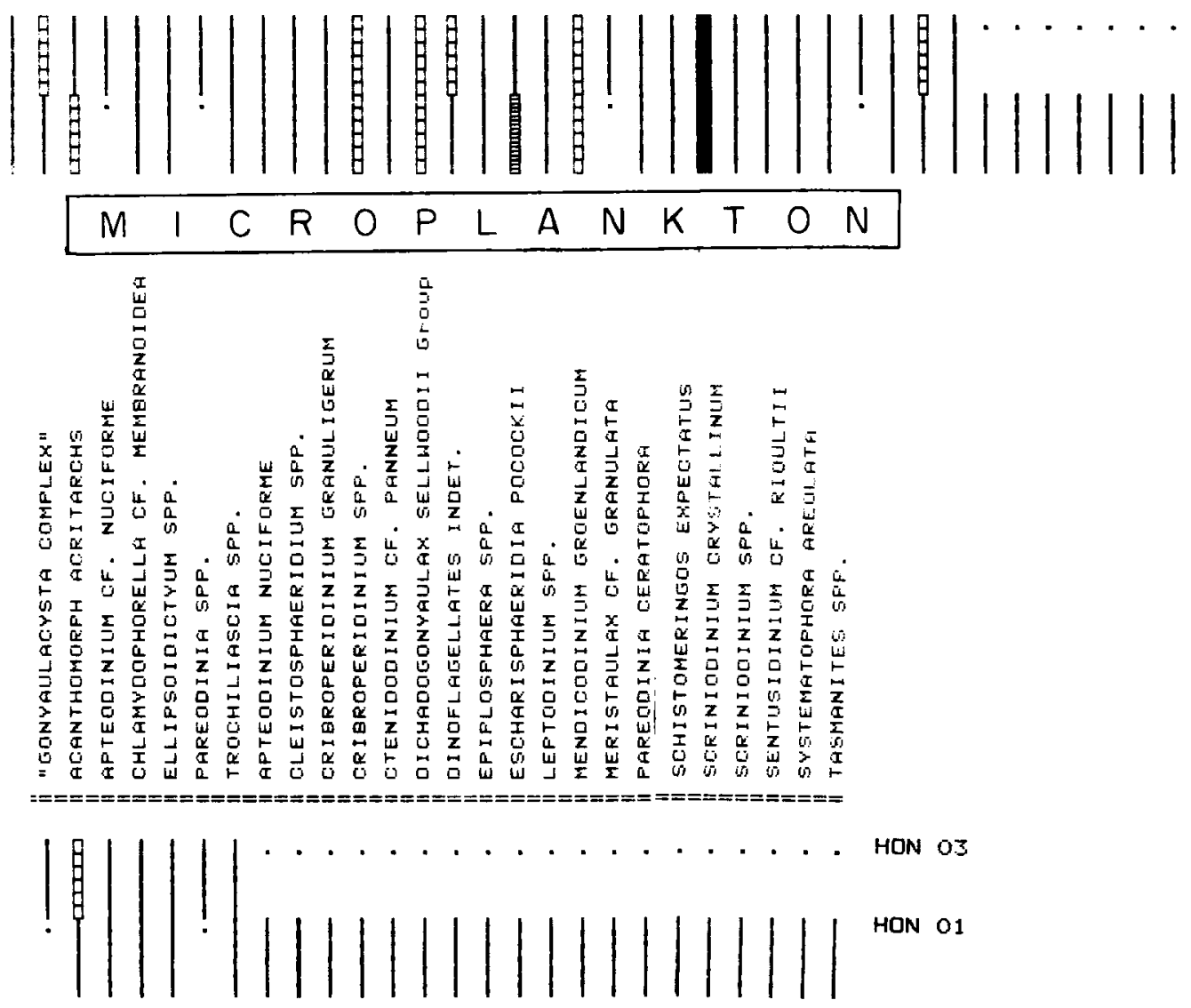

Fig. 6. Distribution chart Hontanar section. 


\section{ACKNOWLEDGMENTS}

The authors wish to thank Veba Oel AG (Gelsenkirchen-Hassel, FR Germany), Veba Oel de Venezuela S.A., Caracas, Venezuela and Shell Internationale Petroleum Maatschappij (SIPM), The Hague, The Netherlands for the permission to publish this paper. They also wish to thank the Laboratory of Palaeobotany and Palynology of the Utrecht State University, the Netherlands for kindly providing the samples for the present investigation. Sincere gratitude is expressed to the Institute of Paleontology of the Free University of Berlin for supplying all possible assistance crucial to the preparation of the manuscript. Special acknowledgement is made to Drs. P. H. Griggs (SIPM, The Hague) and H. Leereveld (Laboratory of Palaeobotany and Palynology, Utrecht) for critically reading the manuscript.

Many thanks are due to Mr. R. van Aarle for the preparation of the illustrations. Appreciation is also extended to M. Bouman (Shell Exploration and Production Company, London), A. Wolfard (Petroleum Development Company Oman, Muscat), H. Leereveld and P. Brugman (Laboratory of Palaeobotany and Palynology, Utrecht) for their contribution during the field excursion of the Laboratory of Palaeobotany and Palynology of Utrecht, The Netherlands.

\section{Manuscript received December 1987.}

Revised manuscript accepted March 1988.

\section{REFERENCES}

Adloff, M. C. \& Doubinger, J., 1978. Associations palynologiques du Trias et du Lias inférieur de l'Quest de l'Europe (Luxembourg, France, Portugal). Palinologiá, núm. extraordinario 1, 21-25.

Adloff, M. C., Doubinger, J. \& Palain, C., 1977. Contribution à la palynologie du Trias et du Lias inférieur du Portugal, "Grès de Silves" du Nord du Tage. Communiacoes do Servicos Geologicas de Portugal, 58 (1974), 91-144.

Alvarado, M., 1980. Introduccion a la Geologia general de España. Boletin Geologico y Minero. T. XCI-I, 65 pp.

Benson, D. G., 1985. Observations and recommendations on the fossil dinocyst genera Ctenidodinium, Dichadogonyaulax and Korystocysta. Tulane studies in Geology and Paleontology Vol. 18, 145-155.

Burger, D., 1966. Palynology of the uppermost Jurassic and lowermost Cretaceous strata in the Eastern Netherlands. Leidse Geologische Mededelingen, 35, 209-276.

Cookson, I. C. \& Eisenack. A., 1960. Upper Mesozoic microplankton from Australia \& New Guinea. Palaeontology, 2, (2), 243-261.

Couper, R. A., 1958. British Mesozoic microspores and pollen grains. Palaeontographica, Abt. B., 103 (4-6), $75-179$.

Courtinat, R. \& Gaillard, C. 1980. Les dinoflagellés des calcaires lites des Trept (Oxfordian Supérieur) inventaire et repartition comparée à celle de la microfaune benthique. Documents des Laboratoires de Geologie de la Faculté des Science de Lyon., 78, 1-123.
Davey, R. J., 1982. Dinocyst stratigraphy of the latest Jurassic to early Cretaceous of the Haldager No. 1 borehole, Denmark. Danmarks Geologiske Undersogelse, Serie B., 6, 1-57.

Davies, E. H., 1985. The miospore and dinoflagellate cyst oppel-zonation of the Lias of Portugal. Palynology, 9, $105-132$.

Dörhöfer, G., 1979. Distribution and stratigraphic utility of Oxfordian to Valanginian miospores in Europe and North America. AASP Contribution Series No. 5B, 101-132.

Fisher, M. J. \& Riley, L. A., 1980. The stratigraphic distribution of dinoflagellate cysts at the boreal JurassicCretaceous boundary. IV International Palynological Conference Lucknow (1976-77) 2, 313-329.

Fritsch, F. E., 1929. Evolutıonary sequences and affinites among Pyrophyta. Biological Reviews 4, 103-151.

Gitmez, G. U., 1970. Dinoflagellate cysts and acritarchs from the basal Kimmeridgian (Upper Jurassic) of England, Scotland and France. Bull. Br. Mus. Nat. Hist. (Geol), Vol. 18, 231-331.

Haeckel, E., 1894. Entwurf eines naturlichen Systems der Organismen auf Grund ihrer Stammegeschichte, Erster Teil: Systematische Phylogenie der Protisten und Pflanzen. Berlin, George Riemer, $400 \mathrm{pp}$.

Hallam, A., 1975. Jurassic environments. Cambridge University Press.

Hermes, J. J., 1978. The stratigraphy of the Subbetic and southern Prebetic of the Velez Rubio-Caravaca area and its bearing on transcurrent faulting in the Betic Cordilleras of southern Spain. Proceedings Koninklijke Nederlandse Akademie voor Wetenschappen, 81, 1-54.

Herngren, G. F. W., Van Hoeken-Klinkenberg, P. M. J. \& De Boer, K. F., 1980. Some remarks on selected palynomorphs near the Jurassic-Cretaceous boundary in the Netherlands. IVth International Palynological Conference Lucknow (1976-1977), 2, 357-3376.

Hunt, Ch. O., 1985. Miospores from the Portland Stone Formation and lower part of the Purbeck Formation (Upper Jurassic/Lower Cretaceous) from Dorset, England. Pollen et Spores, (3-4), 419-451.

Jan du Chêne, R., Masure, E. et al., 1986. Guide practique pour la détermination de kystes de Dinoflagellés fossiles: le complexe Gonyaulacysta. Bull. Centres Rech., Explor.Prod., Elf Aquitaine Mem. 12, 479 pp.

Lentin, J. K. \& Williams, G. L., 1985. Fossil Dinoflagellates: Index to Genera and Species, 1985 Edition. Canadian Technical Report of Hydrography and Ocean Sciences. 60, $451 \mathrm{pp}$.

Lopez Garrido, A. C., 1971. Geología de la zona prebetica, al NE de la provincia de Jaén. Thesis doctor., Universidad de Granada, Espana, 91-204.

Reyre, Y., 1973. Palynologie du Mésozoique Saharien. Memoires du Museum National d'Histoire Naturelle, Serie C, Sciences de la Torre, Tome XXVII, 284 pp.

Riley, L. A., 1974. Miospores from the Upper Jurassic of the Cabo Espichel, Portugal. Symposium on stratigraphical palynology. Birbal Sahni Institute of Palaeobotany, Special publication No. 3, 33-39

Stover, L. E. \& Evitt, W. R., 1978. Analyses of prePleistocene organic-walled dinoflagellates. Publ. Geol. Sci. Univ. Stanford 15, $300 \mathrm{pp}$.

Thusu, B. \& Vigran, J. O., 1975. A review of the palynostratigraphy of the Jurassic System in Norway. NTNF's Continental Shelf Project, Publication No. 67, 1-12. 
Thusu, B. \& Vigran, J. O., 1985. Middle-Late Jurassic (Late Bathonian-Tithonian) Palynomorphs. Journal of Micropalaeontology, 4 (1), 113-130.

Van Erve, A. W. \& Mohr, B. A. R., in press. Palynological investigation in the Upper Jurassic of the vertebrate locality Guimarota (Leiria, Central Portugal).

Viallard, P., 1973. Recherches sur le cycle alpin dans la chaine Iberique sud-occidentale. Traveaux du Lab. de Geol. Mediteer., Associé au CNRS, Univ. Paul Sabatier, Toulouse, 130-139.

Vigran, J. O. \& Thusu, B., 1975. Illustations and distribution of the Jurassic palynomorphs of Norway. NTNF's Continential Shelf Project, Publication No. 65, 1-54.

Williams, G. L. \& Bujak, J. P., 1985. Mesozoic and Cenozoic dinoflagellates. In: Bolli et al. (Eds.): Planktonic Stratigraphy, 847-946.

Woollam, R., 1983. A review of the Jurassic dinocyst genera Ctenidodinum Deflandre 1938 and Dichadogonyaulax Sarjeant 1966. Palynology 7, 183-196.

Woollam, R. \& Riding, J. B., 1983. Dinoflagellate cyst zonation of the English Jurassic. Rep. Inst. Geol. Sci. No. $83 / 2,41 \mathrm{p}$. 